\title{
Sylvatic host associations of Triatominae and implications for Chagas disease reservoirs: a review and new host records based on archival specimens
}

\author{
Anna Y Georgieva ${ }^{1}$, Eric R L Gordon ${ }^{\text {corresp., }}{ }^{1}$, Christiane Weirauch ${ }^{1}$ \\ 1 Department of Entomology, University of California, Riverside, Riverside, California, United States \\ Corresponding Author: Eric R L Gordon \\ Email address: egord003@ucr.edu
}

Background: The 152 extant species of kissing bug include important vectors of the debilitating, chronic, and often fatal Chagas disease, which affects several million people mainly in Central and South America. An understanding of the natural hosts of this speciose group of blood-feeding insects has and will continue to aid ongoing efforts to impede the spread of Chagas disease. However, information on kissing bug biology is piecemeal and scattered, developed using methods with varying levels of accuracy over more than 100 years. Existing host records are heavily biased towards well-studied primary vector species and are derived from primarily three different types of observations, associational, immunological or DNA-based, with varying reliability.

Methods: We gather a comprehensive and unparalleled number of sources reporting host associations via rigorous targeted searches of publication databases to review all known natural, or sylvatic, host records including information on how each record was collected. We integrate this information with novel host records obtained via attempted amplification and sequencing of a $\sim 160$ base pair (bp) region of the vertebrate $12 \mathrm{~S}$ mitochondrial gene from the gastrointestinal tract of 64 archival specimens of Triatominae representing 19 species collected primarily in sylvatic habitats throughout the southern United States and Central and South America during the past 10 years. We show the utility of this method for uncovering novel and under-studied groups of Triatominae hosts, as well as detecting the presence of the Chagas disease pathogen via Polymerase Chain Reaction (PCR) of a $\sim 400$ bp sequence of the trypanosome $18 \mathrm{~S}$ gene.

Results: New host associations for several groups of arboreal mammals were determined including sloths, New World monkeys, coatis, arboreal porcupines and, for the first time as a host of any Triatominae, tayras. A thorough review of previously documented sylvatic hosts, organized by triatomine species and the type of observation (associational, antibody-based, or DNA-based), is presented in a phylogenetic context and highlights large gaps in our knowledge of Triatominae biology.

Conclusion: The application of DNA-based methods of host identification towards additional species of Triatominae, including rarely collected species that may require use of archival specimens, is the most efficient and promising way to resolve recognized shortfalls. 
1 Sylvatic host associations of Triatominae and implications for Chagas disease reservoirs: a

\section{Abstract}

12 Background:

The 152 extant species of kissing bug include important vectors of the debilitating, chronic, and often fatal Chagas disease, which affects several million people mainly in Central and South America. An understanding of the natural hosts of this speciose group of blood-

16 feeding insects has and will continue to aid ongoing efforts to impede the spread of Chagas

17 disease. However, information on kissing bug biology is piecemeal and scattered, developed

18 using methods with varying levels of accuracy over more than 100 years. Existing host records

19 are heavily biased towards well-studied primary vector species and are derived from primarily

20 three different types of observations, associational, immunological or DNA-based, with varying 21 reliability.

23 Methods:

review and new host records based on archival specimens

Short title: Sylvatic hosts of Triatominae

$$
\text { Anna Georgieva*1, Eric Gordon*^1, Christiane Weirauch }{ }^{1}
$$


We gather a comprehensive and unparalleled number of sources reporting host

25 associations via rigorous targeted searches of publication databases to review all known natural,

26 or sylvatic, host records including information on how each record was collected. We integrate

27 this information with novel host records obtained via attempted amplification and sequencing of

$28 \mathrm{a} \sim 160$ base pair (bp) region of the vertebrate $12 \mathrm{~S}$ mitochondrial gene from the gastrointestinal

29 tract of 64 archival specimens of Triatominae, representing 19 species collected primarily in

30 sylvatic habitats throughout the southern United States and Central and South America during

31 the past 10 years. We show the utility of this method for uncovering novel and under-studied

32 groups of Triatominae hosts, as well as detecting the presence of the Chagas disease pathogen

33 via Polymerase Chain Reaction (PCR) of a $\sim 400$ bp sequence of the trypanosome $18 \mathrm{~S}$ gene.

35 Findings:

36 New host associations for several groups of arboreal mammals were determined

37 including sloths, New World monkeys, coatis, arboreal porcupines and, for the first time as a

38 host of any Triatominae, tayras. A thorough review of previously documented sylvatic hosts,

39 organized by triatomine species and the type of observation (associational, antibody-based, or

40 DNA-based), is presented in a phylogenetic context and highlights large gaps in our knowledge

41 of Triatominae biology.

Conclusion:

44 The application of DNA-based methods of host identification towards additional species 45 of Triatominae, including rarely collected species that may require use of archival specimens, is 46 the most efficient and promising way to resolve recognized shortfalls. 


\section{Introduction}

Triatominae, or kissing bugs, are blood-feeding members of the primarily predatory insect family Reduviidae (Order Hemiptera). This subfamily consists of 152 living species, nearly all distributed in the Americas, though several species occur in the Oriental region and

52 53

Triatoma rubrofasciata (De Geer) is considered invasive throughout the tropics [1,2]. These insects are vectors of Trypanosoma cruzi Chagas, the parasite responsible for Chagas disease.

Chagas disease is a chronic debilitating disease, prevalent in Latin America, and affecting up to 10 million people worldwide [3]. There is no vaccine or effective cure once the symptoms of the chronic disease have manifested and the disease has been termed an emerging threat of the 21 st century $[4,5]$.

Most kissing bug species are suspected to be oligo- or polyphagous across a broad range of wild mammal and other vertebrate species [6,7]. Many Triatominae hosts are sylvatic mammals, but domestic mammals such as dogs, cats, and rodents can also be fed upon and act as reservoir hosts of the parasite [8]. Generalist kissing bug species will also feed on humans and some generalist species, e.g., Triatoma infestans Klug and Rhodnius prolixus (Stål), can exhibit infection rates with T. cruzi equal to or even higher than 40\% [9-11] though T. cruzi infection rates vary considerably among populations. Some triatomine species will target certain hosts if available and avoid other potential blood meal sources [1]. Cavernicola pilosa Barber appears to only feed on bats [12,13], while Triatoma delpontei Romaña and Abalos and Psammolestes Bergroth species are usually found in association with various birds [12,14]. In addition, there are reports of some kissing bug species feeding on other arthropods [15-17], feeding on other engorged kissing bug individuals [18] and even facultative nectar feeding [19]. The extent of 
70 these behaviors in a natural environment and for the great majority of kissing bug species is

71 unknown. A diet lacking blood has been shown experimentally to result in complete or increased

72 mortality in at least some species [20], or suggesting that arthropod feeding may be rare or

73 driven by the lack of more suitable hosts. Overall, existing host association data is biased

74 towards a handful of heavily studied and well-documented primary vector species and little data

75 exists for many other Triatominae, particularly in sylvatic habitats [21]. Understanding patterns

76 of host associations across Triatominae can help to identify as yet underappreciated triatomine

77 species of medical interest as well as determine populations of vertebrate hosts that have

78 significant roles in sustaining vectors and potentially serve as reservoir hosts of Trypanosoma

79 cruzi.

80 Records of Triatominae host associations are based on different types of observations that

81 we here classify as associational (i.e. visual observation of a kissing bug in presumed or actual

82 close association with a possible host), immunological, and DNA-based methods. Each of these

83 approaches possess a unique set of advantages and disadvantages. Many early studies on kissing

84 bug-host interactions depended on observations of the insects during laboratory feeding tests or,

85 more rarely, in the wild [12,22]. Despite presenting direct evidence for feeding, laboratory

86 experiments are necessarily unnatural. Laboratory tests either offer insects a single possible host

87 species and observe whether feeding occurs [23-25] or present them with a choice between two

88 or more hosts to determine preference [26]. Both approaches may drive insects to feed on

89 organisms that they would not feed upon in natural habitats. Observations of cohabitation of

90 Triatominae with vertebrates in the wild, e.g., in animal nests and burrows, while more natural,

91 are usually tentative because the association may not reflect actual feeding. There is likely also a

92 bias towards more accessible terrestrial nests and burrows compared to corresponding arboreal 
93 habitats. Immunological methods to detect host associations in Triatominae were first used in the

94 1960s [27-29], seemingly overcoming problems posed by associational methods. By utilizing

95 specific, but often polyclonal, antibodies in antisera developed for a predetermined range of

96 potential host species, experimenters infer direct host associations. Precipitin tests have

97 continued to be a popular way to detect host antigens in Triatominae blood meals [30-32]. While

98 a promising technique for forensic determination of actual hosts, disadvantages of precipitin tests

99 are twofold. First, tests may suffer from non-specificity in antibody binding or irreproducibility

100 as a result of variance in antibodies [33]. Second, due to the cost of developing different sets of

101 antibodies for different groups of hosts, antibodies are typically developed to be specific only for

102 large groups of potential host vertebrates, such as rodents. This approach results in reduced

103 resolution of hosts, i.e. vertebrates are not identified to genus or species, but will also fail to

104 detect unexpected or rare host taxa for which no antibody set is available.

105 More recently, studies have begun to use DNA-based methods to detect host identity

$106[17,34,35]$. These methods typically use PCR that targets the conserved regions of variable,

107 mitochondrial genes for amplification. When amplified sequences are compared to a known

108 database, it is usually possible to determine which species or at least genus of organism the blood

109 originated from. These studies have documented that certain species, such as Triatoma rubida

110 (Uhler), Triatoma protracta (Uhler), and Triatoma gerstaeckeri (Stål), feed on a large variety of

111 vertebrate hosts [17,36]. PCR-based studies also have the potential to determine the percentage

112 of specimens within a given kissing bug population that have fed on humans [36]. While PCR is

113 useful in detecting a wide range of hosts, given that databases such as GenBank now hold a

114 library of barcodes for most mammal species and many other vertebrates, it does have a

115 relatively high risk for human contamination [37]. Primers can also have biases in amplifying 
116 DNA that closely mirrors their sequence while not amplifying other sequences or also amplify

117 the insect's own DNA, which can interfere with detecting host DNA from the blood sample.

118 Multiple blood meals per specimen can amplify and interfere with determining a single sequence

119 and must be separated via cloning of the PCR product or next generation sequencing.

120 While Chagas disease incidence has trended downward in the past thirty years due to

121 screening of blood donations for T. cruzi as well as successful vector control applications of

122 insecticides targeting domiciliated Triatominae species [38], significant challenges remain for

123 further reducing the spread of the disease. One remaining hurdle relates to sylvatic species of

124 Triatominae that continue to transmit Chagas disease to humans primarily in rural areas (e.g.,

125 areas of the Amazon [39]). Studies focusing on the host associations of such species could help

126 to inform policies to limit their impact, for example, by identifying primary vertebrate hosts of

127 sylvatic species. However, most existing studies have focused on known primary vector species

128 and often targeted only domestic or peridomestic habitats where the transmission risk to humans

129 is considered higher (e.g., [40,41]). In addition, most previous DNA-based studies have surveyed

130 narrow geographic areas, with several focusing on North America, and have used only living or

131 very recently preserved specimens. While there are some aggregations of known hosts of

132 Triatominae (e.g., [21]) as well as one analysis of host association patterns using combined

133 precipitin data from 61 studies [42] there exists no comprehensive review of reported

134 Triatominae hosts. In particular, a synthesis of known triatomine-host associations that specifies

135 the method through which the record was obtained and allows for assessing the reliability of the

136 record is yet unavailable. Our study therefore has three objectives: 1) to contribute to the

137 growing knowledge base of host associations across Triatominae, we conducted PCR of

138 gastrointestinal contents extracted from 19 species of Triatominae from a range of localities 
139 (Bolivia to United States); most specimens were collected in sylvatic habitats using light traps

140 and the sample comprises rarely encountered kissing bug species; 2 ) to determine the feasibility

141 of assessing host associations and trypanosome infection for archival kissing bug specimens that

142 have been preserved in ethanol for up to 10 years, we conducted PCR-based identification of

143 host sequences and trypanosomes for 64 specimens; 3 ) to establish currently documented

144 sylvatic host associations, we conducted a thorough literature review for all species of

145 Triatominae while recording the method used to determine that association; host patterns and

146 gaps in our current knowledge were visualized in phylogenetic context for both kissing bug

147 species and vertebrate hosts.

148 Materials and Methods

149 Taxon sampling: Triatominae specimens were primarily collected in sylvatic conditions

150 via light trapping or hand collection throughout the southern United States and Central and South

151 America and were preserved in ethanol (concentrations either unknown or 95\%) between 2005

152 and 2015. We classify the habitat that each specimen as either domestic (found in a residence),

153 peridomestic (found outside in a residential area, near a residence) or sylvatic (found in natural

154 habitats, sometimes near field research stations). It was our aim to survey as wide a variety of

155 Triatominae species as possible, but certain species (e.g., Triatoma protracta, Panstrongylus

156 geniculatus [Latreille]) were sampled more thoroughly due to the availability of specimens

157 present in the Weirauch lab ethanol repository. One specimen of Opisthacidius parkoi (Lent and

158 Wygodzinsky), a close predatory relative of Triatominae, was also sampled and served as a

159 control. Voucher specimen data (unique specimen identifier [USI], determination, sex, specimen

160 depository, collecting locality and event) were recorded using the Planetary Biodiversity Institute

161 instance of the Arthropod Easy Capture database (research.amnh.org/pbi/locality). Images of 
162 voucher specimens were taken using a Leica DFC450 C Microsystems system with a Planapo

163 1.0x objective. Voucher data, including collecting technique and images, are available online at

164 Heteroptera Species Pages (research.amnh.org/pbi/heteropteraspeciespage) and are best searched

165 by species and then USI number.

166 DNA extraction: DNA of the gastrointestinal contents of Triatominae specimens was

167 extracted in order to perform PCR. To avoid cross-contamination as well as the recognized threat

168 of contamination with human DNA, all equipment and work benches were sterilized (dissecting

169 petri dish, forceps, iris scissors) before and after processing each specimen using 10\% bleach.

170 Cuticular surfaces of specimens were sterilized with $1 \%$ bleach for 3 minutes, to eliminate

171 possible contaminants acquired before capture in ethanol or during ethanol storage. The thorax

172 and abdomen were separated and contents of the abdomen were removed with forceps and

173 placed into an Eppendorf tube. While performing this procedure, the sex of the specimen and

174 whether blood was visible in the gut or not was recorded. When a large volume of blood was

175 present, contents were divided into separate Eppendorf tubes. Gut contents were homogenized

176 for 2 minutes with an Eppendorf pestle and DNA was extracted with a QIAGEN DNeasy blood

177 and tissue kit. We recorded the amount of blood in each specimen on a scale of 1 to 4 where: 1 --

178 no material visible in digestive tract; 2 -- small amount of dark, digested blood present; 3 --

179 obvious blood present; 4 -- completely engorged with blood. For seven specimens of Triatoma

180 protracta and one specimen of Eratyrus mucronatus Stål which had been extracted previously,

181 we were not able to record the amount of blood present in the digestive tract.

$182 \quad P C R$ : We tested seven previously developed sets of primers targeting three different

183 mitochondrial genes (Table 1) designed for identification of vertebrate hosts from invertebrate

184 blood meals via PCR on each of our extracts. We were not able to achieve consistent, acceptably 
185 broad or specific results for several sets of previously used primers listed in Table 1 (all those

186 listed without asterisks). These primers amplified the corresponding DNA sequence of certain

187 species of Triatominae or did not amplify DNA that should be present based on the results of

188 other primer sets. We found that the "Kitano" $12 \mathrm{~S}$ primers [43] yielded the most consistent and

189 the greatest number of amplified bands across samples among the primer sets tested and this is

190 the only primer set for which we present results. If samples yielded multiple bands after

191 electrophoresis on 1\% agarose gels, they were gel extracted using QIAquick Gel Extraction kit.

192 If samples extracted from insects containing a large volume of blood did not result in bands after

193 PCR, the extract was diluted 1 in 10 and PCR was conducted again to ensure that a PCR-

194 inhibitor from the blood meal was not present (e.g., approach successful with sample UCR_ENT

195 00123869). We used primers for the $18 \mathrm{~S}$ region to determine presence of trypanosomes in our

196 extracts (Table 1; [44]). PCR conditions consisted of an initial denaturation step of $94^{\circ} \mathrm{C}$ for 5

197 minutes, denaturation at $94^{\circ} \mathrm{C}$ for 30 seconds, the annealing temperature listed in Table 1 for 30

198 seconds, extension at $72^{\circ} \mathrm{C}$ for 30 seconds repeated for 35 cycles with a final extension time at

$19972^{\circ} \mathrm{C}$ for 10 minutes. For each set of PCRs conducted, we also included a blank PCR control that

200 did not result in amplification.

Table 1. Primer sequences and PCR conditions used in this study.

\begin{tabular}{|c|c|c|c|c|c|c|}
\hline DNA target & Primer set & $\begin{array}{c}\text { Locu } \\
\mathbf{s}\end{array}$ & Direction & Sequence & $\begin{array}{l}\text { Annealing } \\
\text { temperature }\end{array}$ & Reference \\
\hline \multirow[t]{9}{*}{ Vertebrate DNA } & Kitano 12S* & $12 \mathrm{~S}$ & $\mathbf{F}$ & 5'-CCC AAA CTG GGA TTA GAT ACC C-3' & $57^{\circ}$ & [45] \\
\hline & & & $\mathbf{R}$ & 5'-GTT TGC TGA AGA TGG CGG TA-3' & & [45] \\
\hline & Melton 12S & $12 \mathrm{~S}$ & $\mathrm{~F}$ & 5-ACT GGG ATT AGA TAC CCC ACT ATG-3 & $53^{\circ}$ & [44] \\
\hline & & & $\mathrm{R}$ & 5'-ATC GAT TAT AGA ACA GGC TCC TC-3' & & [44] \\
\hline & Vert COI & $\mathrm{COI}$ & $\begin{array}{c}\text { M13BC- } \\
\text { FW }\end{array}$ & $\begin{array}{l}\text { 5'-TGT AAA ACG ACG GCC AGT HAA YCA YAA } \\
\text { RGA YAT YGG NAC-3' }\end{array}$ & $45^{\circ}$ & [43] \\
\hline & & & BCV-RV1 & 5'-GCY CAN AYY ATN CYY RTR TA-3' & & [43] \\
\hline & DC-CytB & CytB & UP & 5-CRT GAG GMC AAA TAT CHT TYT-3 & $42.5^{\circ}$ & [46] \\
\hline & & & DW & 5-ART ATC ATT CWG GTT TAA TRT-3 & & [46] \\
\hline & Avian CytB & CytB & $\mathrm{F}$ & 5'-GAC TGT GAC AAA ATC CCN TTC CA-3' & $55^{\circ}$ & [47] \\
\hline
\end{tabular}




\begin{tabular}{|c|c|c|c|c|c|}
\hline & $\begin{array}{c}\text { Mammalian } \\
\text { CytB }\end{array}$ & CytB & $\mathrm{R}$ & $\begin{array}{l}\text { 5'-GGT CTT CAT CTY HGG YTT ACA AGA C-3' } \\
\text { 5'-CGA AGC TTG ATA TGA AAA ACC ATC GTT G- } \\
\text { 3' }\end{array}$ & $55^{\circ}$ \\
\hline & & & $\mathrm{R}$ & 5'-TGT AGT TRT CWG GGT CHC CTA-3' & \\
\hline & Vert CytB & CytB & CB1-L & 5'-CCC CTC AGA ATA TTT GTC CTC A-3' & $57^{\circ}$ \\
\hline & & & CB2-H & 5'-CAT CCA ACA TCT CAG CAT GAT GAA A-3' & \\
\hline $\begin{array}{l}\text { rypanosome } \\
\text { DNA }\end{array}$ & Tez* & $18 S$ & $18 s f$ & 5'-TTA ACG GGA ATA TCC TCA GC-3, & $50^{\circ}$ \\
\hline & & & S829r & 5'-GCA TCA CAG ACC TGC TGT TG-3' & \\
\hline
\end{tabular}

203 (Bioline) before sequencing using the Macrogen EZ-Seq service. Once sequences were obtained,

204 the program Sequencher was used to process chromatographs. A nucleotide similarity BLAST

205 search was then used to compare sequences to the GenBank database. Sequences of the 12S gene

206 were considered to be derived from the same species as the closest match represented in

207 GenBank only if they were $100 \%$ identical and most or all other members of that genus were

208 also represented and differed in sequence (e.g. sequences KX779919, 100\% to Choloepus

209 didactylus [Linnaeus], and KX779929, 100\% to Neotoma lepida Thomas) otherwise we

210 classified it only to genus (e.g., sequence KX779923, 100\% to Lagothrix lagotricha [Humboldt])

211 or to an even higher level (e.g., sequence KX779938, 100\% to Mustela kathiah Hodgson and

212 classified as Mustelidae sp.). When multiple members of a genus were represented in GenBank,

213 but none matched $100 \%$, we classified our sequence to that genus if it was more than $98 \%$

214 identical to one member of the genus and closer to other members of that genus than to any other

215 genus (most sequences, e.g. sequences KX779920 98.6\% to Dasyprocta leporina [Linnaeus] and

216 KX779934 98.7\% to Saguinus oedipus [Linnaeus]). Trypanosome-derived PCR products of the

217 18S rRNA gene were sequenced and the sequence compared to the GenBank database for

218 identification.

219 Phylogeny construction: We gathered all available data for Triatominae species and 220 closely related reduviids (Stenopodainae, Zelurus spp. Opisthacidius spp.) on GenBank totaling 
2219,343 bp from 122 taxa as aligned using the MAFFT EINS-i algorithm [50] comprising the loci

222 from the nuclear rRNA operon and the mitochondrial genome (18S rRNA, ITS 15.8 rRNA and

223 ITS 2, D2, D3-D5 regions of the 28S rRNA; 16S rRNA COI, COII, Cytb) and constructed a

224 phylogeny using a partitioned RaxML analysis (Fig. S1, sampled species in red) partitioned by

225 the best scheme as determined by PartitionFinder (Phylip, Data S1; 9 partitions, Data S2). We

226 excluded Belminus herreri Lent \& Wygodzinsky from our final analysis due to the

227 reconstruction of this taxon as sister to T. rubrofasciata with low support and a long terminal

228 branch; this result may be due to this taxon only being represented by the $18 \mathrm{~S}$ gene that has low

229 phylogenetic utility for relatively recent divergences and the lack of that gene in the only other

230 representative of the tribe Bolboderini in our dataset, Microtriatoma trinidadensis (Lent) (rRNA

231 28S D2 region only). We also excluded two mitochondrial loci: the cytochrome b sequence from

232 Panstrongylus rufotuberculatus (Champion) that has been hypothesized to be introgressed from

233 Panstongylus chinai (Del Ponte) [51] as well as a purported cytochrome oxidase II from $T$.

234 carrioni Larrouse that shares a high similarity to members of the T. infestans clade. To visualize

235 all species of Triatominae in a single figure, we placed all taxa for which reliable molecular data

236 are currently unavailable to this backbone phylogeny using information on morphological

237 similarities from [6].

238 Literature review: We used a Web of Science search (all databases) to query the species

239 name of all the 152 currently recognized extant Triatominae species and surveyed results for

240 literature records of host associations. Briefly, we assessed titles and abstracts for the inclusion

241 of information on host associations for all matches and if we determined that they may include

242 relevant information, we scrutinized the publication for the record of the host association and the

243 type of method with which it was achieved. For a few widely studied triatomine species with an 
244 extremely high number of matching publications (e.g., Triatoma infestans, Rhodnius prolixus),

245 we limited our searches with additional target words such as "gut contents", "blood meal" or

246 "host feed*" to increase the feasibility of surveying all relevant results. Every attempt was made

247 to find the primary source of a host record, but occasionally we resorted to citing reviews for

248 which the source of the record was unclear (and may have been first reported by the authors of

249 that review). We limited the inclusion of host records to evolutionarily relevant host species by

250 excluding laboratory results or host associations of exclusively domestic animals such as dogs,

251 chickens or other farmed animals due to the unnatural and recent modern presence of these hosts.

252 An exception was made for domestic or peridomestic rodents, including mice, rats and guinea

253 pigs that may also occur in natural environments. A detailed protocol for our literature is

254 included as a supplementary document (Article S1). Host taxa were divided into major groups

255 with all arthropods, amphibians, birds and reptiles each comprising a single group and the

256 remaining mammals split primarily by order with some exceptions (suborder level for

257 xenarthrans, superfamily level for primates and rodents, family level for carnivores). A record of

258 Mepraia parapatrica Frías-Lasserre feeding on a sea lion (Otaria flavescens Péron) was not

259 visualized on the figure. While our literature review was as exhaustive as reasonably possible, it

260 is possible that some relevant studies have not been recorded, particularly references in the grey

261 literature (e.g., otherwise unpublished data from theses or technical reports) and others not

262 referenced by Web of Science.

263 Results and Discussion

264 Of 64 total Triatominae specimens tested (38 males and 26 females), we were able to

265 determine a host association for 24 specimens (37.5\%) with a maximum of a single host

266 determined per specimen. Of hosts with observable blood (28 out of 56 with observations 
267 recorded; quantity of blood categories $2-4), 18$ or $64.3 \%$ gave positive host results, compared to

2682 or $7.1 \%$ of those observed without visible blood (category 1 ) in the digestive tract for which we

269 obtained a host sequence. Specimens with observable blood but without amplifiable host DNA

270 may represent samples with DNA degraded beyond allowing for amplification with primers

271 targeting the $\sim 160 \mathrm{bp}$ region of the $12 \mathrm{~S}$ gene. Alternatively, it is possible that the Kitano $12 \mathrm{~S}$

272 primers do not amplify $12 \mathrm{~S}$ sequences from certain hosts, though they were designed based on

273 sequences from divergent vertebrates from sharks to fish, reptiles, amphibians and mammals

274 (Kitano 2007). Of the 24 specimens with host determinations, 17 or $70.8 \%$ were male, a heavily

275 skewed ratio. Similarly, of the 28 specimens with visible blood in the digestive tract, 21 or $75 \%$

276 were male. We speculate that blood-fed males may be more predisposed to dispersing in flight

277 while searching for mates and thus be more susceptible to light traps. In contrast, females may be

278 stationary after feeding, attempting to find a suitable place for oviposition, possibly near or in the

279 same location as the source of a blood meal. The infection rate of all specimens with $T$. cruzi

280 across sampled Triatominae was $31.3 \%$ or 20 specimens with one specimen of Rhodnius pictipes

281 Stål producing a band that, after sequenced, matched that of Trypanosoma rangeli Tejera. Of the

28220 specimens testing positive for T. cruzi, 50\% also possessed detectable host DNA and $50 \%$ did

283 not. Panstrongylus geniculatus was the species with the highest number of T. cruzi positive

284 individuals (5/11) followed by Triatoma protracta (4/17) and all three individuals tested of $T$.

285 dimidiata (Latrielle) which was the species with the highest positive percentage rate $(100 \% ; 3 / 3)$

286 along with the single positive specimens of $T$. dispar Lent and T. recurva Stål. Specimens of

287 seven additional species also tested positive for $T$. cruzi (Table 2), all of which were previously

288 known to be capable of hosting the parasite [7]. 


\section{DNA targeted PCR.}

\begin{tabular}{|c|c|c|c|c|c|c|c|c|c|c|c|c|}
\hline USI & Species & $\begin{array}{c}\text { COUNTRY: } \\
\text { Primary } \\
\text { subdivision }\end{array}$ & Ecotype & $\begin{array}{c}\text { Collecting } \\
\text { date } \\
\text { (year) }\end{array}$ & $\begin{array}{c}\text { EtOH } \\
\text { concentration }\end{array}$ & Sex & $\begin{array}{c}\text { Quantity } \\
\text { of blood } \\
(1-4)\end{array}$ & $\begin{array}{l}\text { Host 12S } \\
\text { sequence }\end{array}$ & $\begin{array}{c}\text { Top BLAST } \\
\text { hit of host 12S } \\
\text { sequence } \\
\end{array}$ & Inferred host & $\begin{array}{c}\text { Trypanosome } \\
\text { sequence }\end{array}$ & $\begin{array}{c}\text { Top } \\
\begin{array}{c}\text { trypanosome } \\
\text { BLAST hit }\end{array} \\
\end{array}$ \\
\hline $\begin{array}{c}\text { UCR_ENT } \\
00012958 \\
\end{array}$ & $\begin{array}{c}\text { Eratyrus } \\
\text { mucronatus }\end{array}$ & PERU; Loreto & Sylvatic & 2007 & $?$ & $\mathrm{M}$ & $\mathrm{NA}$ & & & & & \\
\hline $\begin{array}{l}\text { UCR ENT } \\
00012937\end{array}$ & $\begin{array}{c}\text { Opisthacidius } \\
\text { parkoi }\end{array}$ & PERU; Loreto & Sylvatic & 2007 & ? & F & NA & & & & & \\
\hline $\begin{array}{l}\text { UCR ENT } \\
00119043\end{array}$ & $\begin{array}{l}\text { Panstrongylus } \\
\text { geniculatus }\end{array}$ & $\begin{array}{l}\text { FRENCH } \\
\text { GUIANA; } \\
\text { Cayenne }\end{array}$ & Sylvatic & 2010 & $95 \%$ & $\mathrm{M}$ & 4 & KX779934 & $\begin{array}{l}98.7 \% \text { to } \\
\text { Saguinus } \\
\text { oedipus }\end{array}$ & $\begin{array}{l}\text { Saguinus sp. } \\
\text { (Tamarin) }\end{array}$ & & \\
\hline $\begin{array}{l}\text { UCR ENT } \\
00119044\end{array}$ & $\begin{array}{l}\text { Panstrongylus } \\
\text { geniculatus }\end{array}$ & $\begin{array}{l}\text { FRENCH } \\
\text { GUIANA; } \\
\text { Cayenne }\end{array}$ & Sylvatic & 2010 & $95 \%$ & M & 3 & KX779919 & $\begin{array}{c}100 \% \text { to } \\
\text { Cholopus } \\
\text { didactylus }\end{array}$ & $\begin{array}{c}\text { Choloepus } \\
\text { didactylus } \\
\text { (Southern two- } \\
\text { toed sloth) }\end{array}$ & & \\
\hline $\begin{array}{l}\text { UCR ENT } \\
00119045\end{array}$ & $\begin{array}{l}\text { Panstrongylus } \\
\text { geniculatus }\end{array}$ & $\begin{array}{l}\text { FRENCH } \\
\text { GUIANA; } \\
\text { Cayenne }\end{array}$ & Sylvatic & 2010 & $95 \%$ & M & 1 & & & & & \\
\hline $\begin{array}{l}\text { UCR ENT } \\
00119046\end{array}$ & $\begin{array}{l}\text { Panstrongylus } \\
\text { geniculatus }\end{array}$ & $\begin{array}{l}\text { FRENCH } \\
\text { GUIANA; } \\
\text { Cayenne }\end{array}$ & Sylvatic & 2010 & $95 \%$ & $\mathrm{~F}$ & 1 & KX779920 & $\begin{array}{l}\text { 98.6\% to } \\
\text { Dasyprocta } \\
\text { leporina }\end{array}$ & $\begin{array}{c}\text { Dasyprocta sp. } \\
\text { (Agouti) }\end{array}$ & KX779898 & $\begin{array}{c}100 \% \text { to } \\
\text { Trypanosoma } \\
\text { cruzi }\end{array}$ \\
\hline $\begin{array}{l}\text { UCR ENT } \\
00119047\end{array}$ & $\begin{array}{l}\text { Panstrongylus } \\
\text { geniculatus }\end{array}$ & $\begin{array}{c}\text { FRENCH } \\
\text { GUIANA; } \\
\text { Cayenne }\end{array}$ & Sylvatic & 2010 & $95 \%$ & F & 1 & & & & & \\
\hline $\begin{array}{l}\text { UCR ENT } \\
00012932\end{array}$ & $\begin{array}{l}\text { Panstrongylus } \\
\text { geniculatus }\end{array}$ & PERU; Loreto & Sylvatic & 2007 & ? & M & 4 & KX779923 & $\begin{array}{l}100 \% \text { to } \\
\text { Lagothrix } \\
\text { lagotricha }\end{array}$ & $\begin{array}{l}\text { Lagothrix sp. } \\
\text { (Wooly } \\
\text { monkey) }\end{array}$ & KX779901 & $\begin{array}{c}100 \% \text { to } \\
\text { Trypanosoma } \\
\text { cruzi }\end{array}$ \\
\hline $\begin{array}{l}\text { UCR ENT } \\
00063360\end{array}$ & $\begin{array}{l}\text { Panstrongylus } \\
\text { geniculatus }\end{array}$ & $\begin{array}{l}\text { NICARAGUA; } \\
\text { Rio San Juan }\end{array}$ & Sylvatic & 2010 & $95 \%$ & M & 3 & KX779922 & $\begin{array}{c}97.1 \% \text { to } \\
\text { Dasyprocta } \\
\text { punctata }\end{array}$ & $\begin{array}{c}\text { Dasyprocta sp. } \\
\text { (Agouti) }\end{array}$ & KX779905 & $\begin{array}{c}100 \% \text { to } \\
\text { Trypanosoma } \\
\text { cruzi }\end{array}$ \\
\hline $\begin{array}{c}\text { UCR ENT } \\
00063367 \\
\end{array}$ & $\begin{array}{c}\begin{array}{c}\text { Panstrongylus } \\
\text { geniculatus }\end{array} \\
\end{array}$ & $\begin{array}{c}\text { BOLIVIA; Santa } \\
\text { Cruz } \\
\end{array}$ & Sylvatic & 2009 & $95 \%$ & $\mathrm{M}$ & 2 & & & & & \\
\hline $\begin{array}{l}\text { UCR ENT } \\
00119054\end{array}$ & $\begin{array}{l}\text { Panstrongylus } \\
\text { geniculatus }\end{array}$ & $\begin{array}{l}\text { COSTA RICA; } \\
\text { Heredia }\end{array}$ & Sylvatic & 2013 & $95 \%$ & M & 2 & KX779938 & $\begin{array}{c}100 \% \text { to } \\
\text { Mustela kathiah }\end{array}$ & $\begin{array}{l}\text { Mustelidae sp. } \\
\text { (Weasels, } \\
\text { badgers, otters } \\
\text { and allies) }\end{array}$ & KX779914 & $\begin{array}{c}100 \% \text { to } \\
\text { Trypanosoma } \\
\text { cruzi }\end{array}$ \\
\hline $\begin{array}{l}\text { UCR ENT } \\
00123859\end{array}$ & $\begin{array}{l}\text { Panstrongylus } \\
\text { geniculatus }\end{array}$ & PANAMA; Colon & Sylvatic & 2008 & ? & $\mathrm{F}$ & 1 & & & & KX779915 & $\begin{array}{c}100 \% \text { to } \\
\text { Trypanosoma } \\
\text { cruzi }\end{array}$ \\
\hline $\begin{array}{l}\text { AMNH_PBI } \\
00021872\end{array}$ & $\begin{array}{l}\text { Panstrongylus } \\
\text { lignarius }\end{array}$ & $\begin{array}{l}\text { FRENCH } \\
\text { GUIANA; } \\
\text { Montsinery }\end{array}$ & Sylvatic & 2004 & ? & $\mathrm{M}$ & 2 & & & & KX779910 & $\begin{array}{c}100 \% \text { to } \\
\text { Trypanosoma } \\
\text { cruzi }\end{array}$ \\
\hline $\begin{array}{l}\text { UCR ENT } \\
00012933\end{array}$ & $\begin{array}{c}\text { Panstrongylus } \\
\text { rufotuberculatus }\end{array}$ & PERU; Loreto & Sylvatic & 2007 & ? & M & 3 & KX779933 & $\begin{array}{l}99.4 \% \text { to } \text { Ateles } \\
\text { belzebuth }\end{array}$ & $\begin{array}{l}\text { Ateles sp. } \\
\text { (Spider } \\
\text { monkey) }\end{array}$ & & \\
\hline $\begin{array}{c}\text { UCR_ENT } \\
00063350\end{array}$ & $\begin{array}{c}\text { Panstrongylus } \\
\text { rufotuberculatus }\end{array}$ & $\begin{array}{l}\text { BOLIVIA; Santa } \\
\text { Cruz }\end{array}$ & Sylvatic & 2009 & $95 \%$ & M & 1 & KX779925 & $\begin{array}{c}100 \% \text { to Homo } \\
\text { sapiens }\end{array}$ & $\begin{array}{c}\text { Homo sapiens } \\
\text { (Human) }\end{array}$ & & \\
\hline $\begin{array}{c}\text { UCR_ENT } \\
00012961 \\
\end{array}$ & $\begin{array}{c}\text { Panstrongylus } \\
\text { rufotuberculatus }\end{array}$ & PERU; Loreto & Sylvatic & 2007 & $?$ & $\mathrm{M}$ & 2 & & & & & \\
\hline $\begin{array}{l}\text { UCR ENT } \\
00063364\end{array}$ & $\begin{array}{c}\text { Panstrongylus } \\
\text { rufotuberculatus }\end{array}$ & $\begin{array}{l}\text { NICARAGUA; } \\
\text { Rio San Juan }\end{array}$ & Sylvatic & 2010 & $95 \%$ & M & 3 & KX779940 & $\begin{array}{c}98.5 \% \text { to } \\
\text { Coendou } \\
\text { prehensilis }\end{array}$ & $\begin{array}{l}\text { Coendou sp. } \\
\text { (Prehensile- } \\
\text { tailed } \\
\text { porcupine) }\end{array}$ & KX779907 & $\begin{array}{c}100 \% \text { to } \\
\text { Trypanosoma } \\
\text { cruzi }\end{array}$ \\
\hline $\begin{array}{l}\text { UCR_ENT } \\
00003254 \\
\end{array}$ & $\begin{array}{c}\text { Paratriatoma } \\
\text { hirsuta }\end{array}$ & USA; California & Peridomestic & 2009 & $95 \%$ & $\mathrm{M}$ & 4 & & & & & \\
\hline $\begin{array}{c}\text { UCR ENT } \\
00012924\end{array}$ & Rhodnius barretti & PERU; Loreto & Sylvatic & 2007 & ? & $\mathrm{F}$ & 1 & KX779937 & $\begin{array}{c}99.3 \% \text { to } \\
\text { Saimiri sciureus }\end{array}$ & $\begin{array}{c}\text { Saimiri sp. } 3 \\
\text { (Squirrel } \\
\text { monkey) }\end{array}$ & & \\
\hline $\begin{array}{c}\text { UCR_ENT } \\
00012925\end{array}$ & Rhodnius barretti & PERU; Loreto & Sylvatic & 2007 & $?$ & $\mathrm{M}$ & 1 & & & & & \\
\hline $\begin{array}{l}\text { UCR ENT } \\
00012929\end{array}$ & Rhodnius barretti & PERU; Loreto & Sylvatic & 2007 & ? & M & 4 & KX779918 & $\begin{array}{c}100 \% \text { to Saimiri } \\
\text { sciureus }\end{array}$ & $\begin{array}{c}\text { Saimiri sp. 1 } \\
\text { (Squirrel } \\
\text { monkey) }\end{array}$ & & \\
\hline $\begin{array}{l}\text { UCR ENT } \\
00012928\end{array}$ & Rhodnius barretti & PERU; Loreto & Sylvatic & 2007 & $?$ & F & 1 & & & & & \\
\hline $\begin{array}{l}\text { UCR ENT } \\
00002734\end{array}$ & Rhodnius barretti & $\begin{array}{l}\text { ECUADOR; } \\
\text { Orellana }\end{array}$ & Sylvatic & 2009 & $95 \%$ & M & 3 & KX779921 & $\begin{array}{c}99.4 \% \text { to } \\
\text { Saimiri sciureus }\end{array}$ & $\begin{array}{c}\text { Saimiri sp. } 2 \\
\text { (Squirrel } \\
\text { monkey) } \\
\end{array}$ & KX779912 & $\begin{array}{c}100 \% \text { to } \\
\text { Trypanosoma } \\
\text { cruzi }\end{array}$ \\
\hline $\begin{array}{l}\text { UCR ENT } \\
00002735\end{array}$ & Rhodnius barretti & $\begin{array}{l}\text { ECUADOR; } \\
\text { Orellana }\end{array}$ & Sylvatic & 2009 & $95 \%$ & F & 1 & & & & KX779900 & $\begin{array}{c}100 \% \text { to } \\
\text { Trypanosoma } \\
\text { cruzi }\end{array}$ \\
\hline $\begin{array}{l}\text { UCR ENT } \\
00119053\end{array}$ & Rhodnius barretti & $\begin{array}{l}\text { PERU; Madre de } \\
\text { Dios }\end{array}$ & Sylvatic & 2005 & $95 \%$ & F & 4 & KX779924 & $\begin{array}{l}99.4 \% \text { to } \\
\text { various Cebus } \\
\text { spp. }\end{array}$ & $\begin{array}{c}\text { Cebus sp. } 2 \\
\text { (Gracile } \\
\text { capuchin } \\
\text { monkey) } \\
\end{array}$ & & \\
\hline $\begin{array}{l}\text { UCR ENT } \\
00063365\end{array}$ & $\begin{array}{c}\text { Rhodnius } \\
\text { pallescens }\end{array}$ & $\begin{array}{l}\text { NICARAGUA; } \\
\text { Rio San Juan }\end{array}$ & Sylvatic & 2010 & $95 \%$ & M & 1 & & & & & \\
\hline $\begin{array}{c}\text { UCR_ENT } \\
00002736 \\
\end{array}$ & $\begin{array}{c}\text { Rhodnius } \\
\text { pictipes }\end{array}$ & $\begin{array}{l}\text { ECUADOR; } \\
\text { Orellana }\end{array}$ & Sylvatic & 2009 & $95 \%$ & $\mathrm{~F}$ & 1 & KX779936 & $\begin{array}{c}100 \% \text { to Homo } \\
\text { sapiens }\end{array}$ & $\begin{array}{c}\text { Homo sapiens } \\
\text { (Human) }\end{array}$ & & \\
\hline $\begin{array}{l}\text { UCR ENT } \\
00119039\end{array}$ & $\begin{array}{l}\text { Rhodnius } \\
\text { pictipes }\end{array}$ & $\begin{array}{l}\text { FRENCH } \\
\text { GUIANA; } \\
\text { Cayenne }\end{array}$ & Sylvatic & 2010 & $95 \%$ & $\mathrm{~F}$ & 1 & & & & & \\
\hline $\begin{array}{l}\text { UCR ENT } \\
00119040\end{array}$ & $\begin{array}{l}\text { Rhodnius } \\
\text { pictipes }\end{array}$ & $\begin{array}{c}\text { FRENCH } \\
\text { GUIANA; } \\
\text { Cayenne }\end{array}$ & Sylvatic & 2010 & $95 \%$ & F & 1 & & & & & \\
\hline $\begin{array}{l}\text { UCR_ENT } \\
00119041\end{array}$ & $\begin{array}{l}\text { Rhodnius } \\
\text { pictipes }\end{array}$ & $\begin{array}{l}\text { FRENCH } \\
\text { GUIANA; } \\
\text { Cayenne }\end{array}$ & Sylvatic & 2010 & $95 \%$ & M & 4 & & & & KX779911 & $\begin{array}{c}100 \% \text { to } \\
\text { Trypanosoma } \\
\text { rangeli }\end{array}$ \\
\hline $\begin{array}{l}\text { UCR ENT } \\
00063354\end{array}$ & $\begin{array}{l}\text { Rhodnius } \\
\text { robustus }\end{array}$ & $\begin{array}{c}\text { BOLIVIA; Santa } \\
\text { Cruz } \\
\end{array}$ & Sylvatic & 2009 & $95 \%$ & $\mathrm{~F}$ & 4 & KX779932 & $\begin{array}{l}99.4 \% \text { to } \text { Nasua } \\
\text { nasua }\end{array}$ & $\begin{array}{c}\text { Nasua sp. } \\
\text { (Coati) }\end{array}$ & KX779904 & $\begin{array}{c}100 \% \text { to } \\
\text { Trypanosoma } \\
\text { cruzi }\end{array}$ \\
\hline $\begin{array}{l}\text { UCR ENT } \\
00123871\end{array}$ & $\begin{array}{l}\text { Triatoma } \\
\text { dimidiata }\end{array}$ & $\begin{array}{l}\text { COSTA RICA; } \\
\text { Heredia }\end{array}$ & Sylvatic & 2010 & $95 \%$ & M & 4 & & & & KX779899 & $\begin{array}{c}100 \% \text { to } \\
\text { Trypanosoma } \\
\text { cruzi }\end{array}$ \\
\hline
\end{tabular}




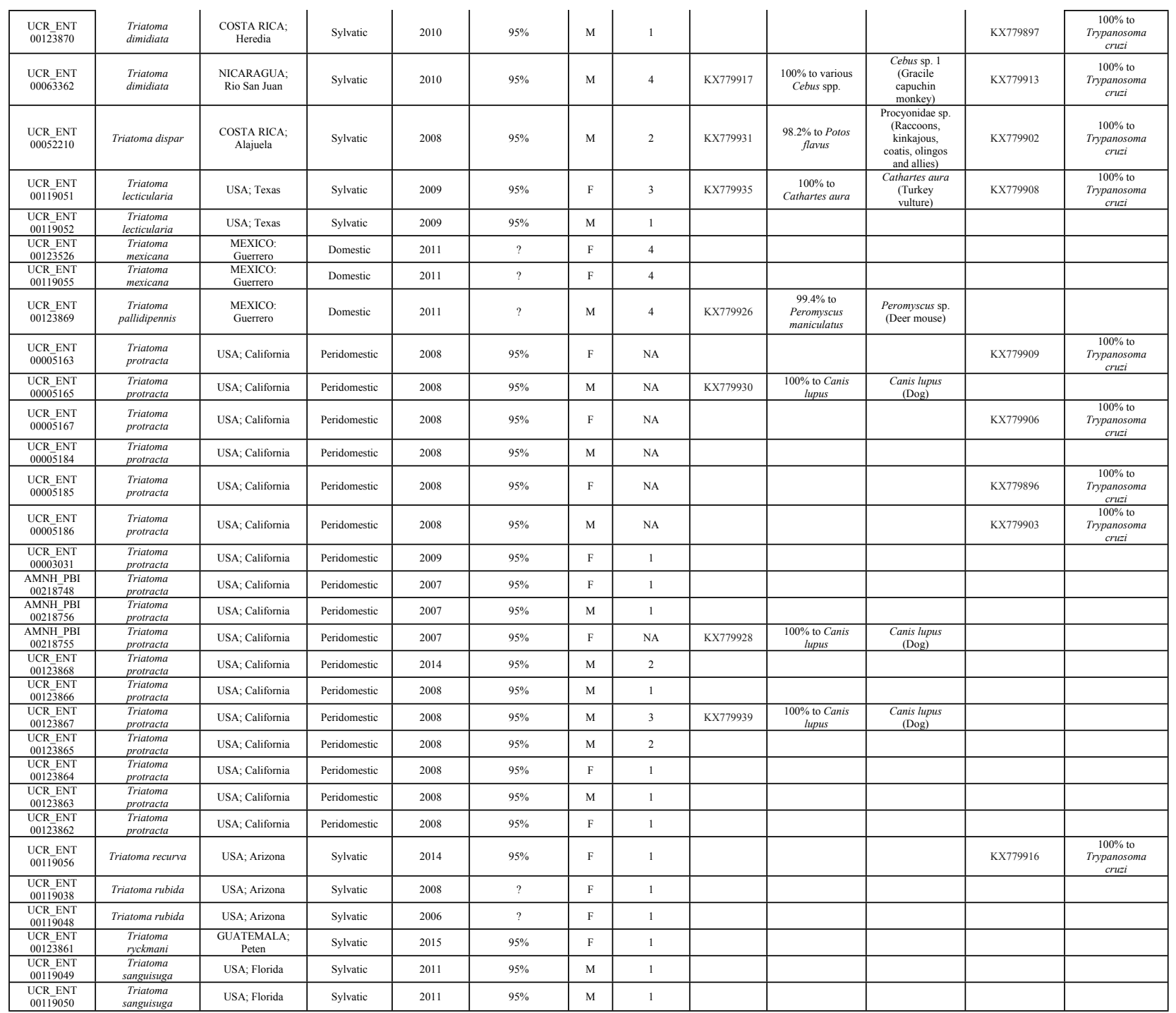

We did not see evidence of double peaks in our chromatographs and direct sequencing

293 always resulted in a single, uncontroversial host sequence, similar to results from other studies

294 conducted using similar primers [52], but in contrast to other studies where cloning of the PCR

295 product was performed and as many as four hosts were detected from a single specimen [53].

296 The archival nature of our specimens may have contributed towards the lack of detection of

297 blood meals other than the one with most abundant DNA available. The 24 hosts detected

298 represented mainly animals present in a sylvatic environment with the exception of three records

299 of the domestic dog from T. protracta $(\mathrm{n}=17)$ specimens collected in Southern California in 
300 residential areas, one record of a deer mouse detected from T. pallidipennis Stål $(\mathrm{n}=1)$ at a

301 residence in Mexico and two records of humans from sylvatic areas in Ecuador and Bolivia from

302 Rhodnius pictipes $(\mathrm{n}=4)$ and Panstrongylus rufotuberculatus $(\mathrm{n}=3)$, respectively. These results

303 represent fewer human records than some similar DNA-based studies (48.8\% in [53]; $38 \%$ in

304 [36]), which may reflect the sylvatic nature of most of our collecting sites and, potentially, the

305 rigorous sterilization protocol we utilized. Because we did not obtain any sequences from

306 marsupials or armadillos, it is possible that the Kitano $12 \mathrm{~S}$ primers do not amplify $12 \mathrm{~S}$ sequences

307 from these hosts. While the primers match the corresponding sequence from armadillos at all but

308 two mismatches at beginning of the reverse primer, the sequence in opossums appears to have

309 several mismatches with the reverse primer that may have prevented binding and amplification.

310 Of the sylvatic hosts detected, many are arboreal mammals and a surprising number reflect new

311 host species, or new records for the larger groups of vertebrates they belong to (Fig. 1, dark red

312 rectangles) as defined in Figure 1. Even after an extensive literature review, we were unable to

313 find any record of these new groups of animals being recorded for hosts of these species. The

314 new hosts detected for Panstrongylus geniculatus (n=11) include sloths (Choloepus didactylus

315 Linnaeus), the arboreal weasel-like animal known as a tayra (Eira barbara [Linnaeus]), an

316 unidentified member of Mustelidae, New World monkeys (Lagothrix sp. and Saguinus sp.) and

317 agoutis (Dasyprocta sp.), all but the last, representing the first record for that group of vertebrate

318 for that species. The tayra record represents the first record of any Triatominae species feeding

319 on this species though it has been previously known to be infected with $T$. cruzi [54]. We

320 recovered several new host records for New World monkeys, apart from the two species

321 identified for $P$. geniculatus, including Saimiri sp., Ateles sp., and Cebus sp. For Rhodnius

322 barretti $(\mathrm{n}=7)$, Panstrongylus rufotuberculatus $(\mathrm{n}=3)$ and $T$. dimidiata $(\mathrm{n}=3)$, respectively. These 
323 all represent the first New World monkey hosts recorded for those species except for $T$.

324 dimidiata which has been previously noted as possessing antigens reacting to antibodies

325 developed for detecting New World monkey specific proteins. Our new host records also

326 included the arboreal porcupine genus Coendou for P. rufotuberculatus, coati (Nasua sp.) for $R$.

327 robustus $(\mathrm{n}=1)$ and a sequence with the closest match to a kinkajou (Potos $s p$.) but only

328 determined to the level of Procyonidae for Triatoma dispar $(\mathrm{n}=1)$, all new animal groups for

329 those species. The prevalence of arboreal mammals among our new host records may reflect the

330 inaccessibility of these habitats for gathering associational observations or absence of antigens

331 targeting these taxa in previous studies. For example, while various populations of non-human

332 primates are known to have high infection rates with T. cruzi [55] and were even one of the first

333 mammals found to be infected with this parasite [8], only six species of Triatominae had

334 previously been recorded in association with New World monkeys with four new records (and

335 three new species) in this study alone. Potentially, these under recognized groups of hosts play a

336 more prominent role in the sylvatic cycle of $T$. cruzi than has been previously understood. 


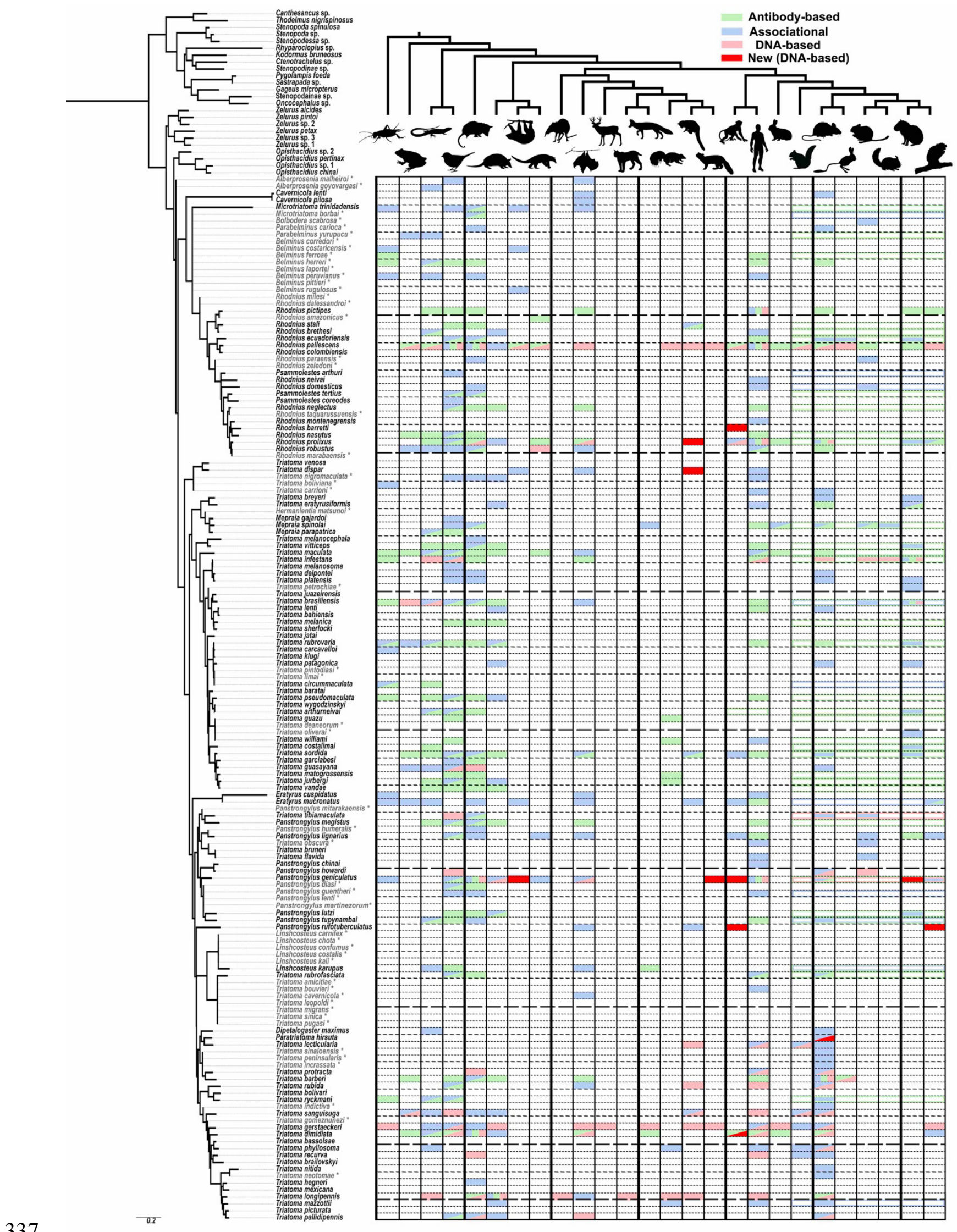


Figure 1. A visualization of the known sylvatic hosts of Triatominae and the type of record(s) supporting that association. The animals at the top of the figure represent the following groups from left to right, alternating from top to bottom: arthropod (Arthropoda), amphibian (Amphibia), lizards (Lepidosauromorpha), bird (Aves), opossums (Didelphimorphia), armadillo (Cingulata), sloth (Folivora), anteater (Vermilingua), shrew (Eulipotyphla), bat (Chiroptera), even-toed ungulate (Artiodactyls), feline (Felidae), canine (Canidae), musteloid (Mephitidae; Skunk), musteloid (Procyonidae; Racoons and relatives), musteloid (Mustelidae; Weasel), platyrrhine monkey (Ceboidea), human (Hominidae), rabbits (Lagomorpha), rodent (Sciuromorpha), rodent (Muroidea), rodent (Geomyoidea), rodent (Octodontoidea), rodent (Chinchilloidea), rodent (Cavioidea), rodent (Erethizontoidea). Relationships among mammals were simplified from [56] for Carnivora, [57] for deep level relationships and [58] for rodents. Triatominae taxa in light grey and indicated with an asterisk were added to the phylogeny based on morphological similarities indicated in the literature. Filled in matrix rectangle indicate observations with green indicating antibody-based observations; blue, associational; and red, DNA-based with bright red indicating newly obtained DNA-based host records for that species in our study. Colored outlines of rectangles across all represented rodent superfamilies represent observations specified only to a monophyletic higher level, e.g., the order Rodentia or Primates.

As a result of our literature review, we were able to detect some feeding patterns that

352 have not been previously widely recognized. However, it should be noted that host preferences

353

354

355

356

358

359

360

361

362

363

364

365

366

367

368

369 cannot be determined with this kind of data nor does the lack of evidence for a particular host

suggest that this host association may not be uncovered in the future. All of our aggregated data

associations with amphibians (14), reptiles (35) and birds (55, or 36\% of all Triatominae species)

is higher than we expected as these species tend to be thought of as minor hosts for Triatominae

or are primarily associated only with certain species [42]. This discrepancy may reflect that these

hosts are not known to be able to harbor the $T$. cruzi pathogen $[59,60]$ and deliberate attention

has been paid to mammalian reservoir hosts. The most common group of known hosts among all

species of Triatominae are marsupials (55 species), birds (55 species), humans (51) and

Muroidea including rats and mice ( 47 species). Some of the rarest groups of known sylvatic

hosts are shrews, artiodactyls, felines and sea lions, each known only from a single host record,

although this excludes records for domestic species classified in these groups such as the

domestic cat and the domestic pig. There are 40 kissing bug species for which we were unable to

find any records for sylvatic hosts. The largest group of Triatominae with scarce host data are the

Old World species including the genus Linshcosteus and the T. rubrofasciata species group.

Species which have been studied using DNA-based methods tend to have a broader range of

known hosts than species only investigated using associational and immunological approaches. 
370 For example, Rhodnius pallescens Barber and T. gerstaeckeri have the broadest ranges of

371 recorded host groups (20 and 15 respectively, out of 26 groups recorded across all species)

372 primarily because of single studies focused on each of those species [52,61]. Some species

373 thought to have narrow host ranges show some evidence, although mostly associational and

374 rarely antibody-based, of also feeding on additional hosts such as rodents for Cavernicola

375 (thought to associate with bats) and both rodents and marsupials for Psammolestes (thought to

376 associate with birds). There is no obvious host specificity of Triatominae clades and, overall, our

377 review points towards the generalist bent of the great majority Triatominae species, perhaps

378 influenced more by hosts present in a given habitat and microhabitat than innate preference

379 towards certain groups of hosts.

380 A comprehensive understanding of the ecology of Trypanosoma cruzi and relevant

381 vectors, including primarily sylvatic Triatominae species, will be important in further controlling

382 Chagas disease. One important consideration in any eventual attempt to eradicate Chagas disease

383 is that oral transmission in the sylvatic cycle may be the primary mechanism of parasite spread

384 [62] and some insectivorous mammals often have a higher prevalence of the disease [63]. It has

385 been reported that even T. cruzi-infected vertebrates eaten as prey can be infective [64] and it

386 appears that Chagas disease can "bioaccumulate" in predators including highly carnivorous top

387 predators (e.g., ocelots), that are nocturnal without permanent dens and are thus unlikely to be

388 exposed to feeding Triatominae [65]. Predators that probably are frequently exposed to

389 Triatominae, for example nest-building arboreal species like coatis and tayras, play an important

390 role in the maintenance and spread of T. cruzi. For that reason, it has been predicted that if there

391 was development of a successful vaccine against $T$. cruzi in the future, targeting such predators

392 for vaccines among other highly-infected host species could theoretically be an effective strategy 
393 in limiting the disease [66]. Thus, the confirmation of Triatominae feeding on certain carnivores

394 near the top of the food web can be of major importance in understanding and limiting the

395 sylvatic cycle of $T$. cruzi.

396 New approaches for modeling networks of vector host interactions based on the co-

397 occurrence of mammal and Triatominae species offer a promising method for understanding

398 Triatominae ecology $[67,68]$. Combining such studies with reviews of T. cruzi-infected

399 mammals [69] as well as documented host associations of individual species such as provided in

400 our review offers a route for advancing our understanding of the spread of Trypanosoma cruzi.

401 While each individual study does not manage to sample a completely representative population

402 of vectors and is limited in their recovery of host identity by methodology-specific biases, a

403 synthetic record of host associations overcomes many shortcomings.

\section{Conclusion}

We believe that DNA-based methods for determining host associations of blood-feeding species offer the best route forward in understanding the biology and epidemiological importance of this speciose group of vectors. While there may be bias in representation of known vertebrates on public databases, these databases continue to encompass data for an ever-growing range of species. We recommend the deposition of sequences acquired from vertebrate hosts of vectors

410 into public databases even if their identity is not known at the time, a practice not yet routinely

411 conducted, as the influx of DNA data may later shed light on their identity. While DNA-based

412 studies of blood meals can suffer from primer specificity biases, rigorous testing of primers sets

413 for universality and specificity can minimize this possibility. We have shown that this method

414 can be used on archival specimens and we recommend future efforts using this relatively cheap,

415 efficient and effective method in order to better understand the habits of all species of these 
416 vectors, particularly those that are less well studied or rarely collected. PCR on archival

417 specimens may sometimes give false negative results or only allow sequencing of the most

418 recent host, but this is preferable to over reactivity of antibody based tests [70] and can be

419 overcome given a sufficiently large enough sample size. We found that $95 \%$ ethanol seemed to

420 preserve DNA well enough for amplification of the 150 bp chunk of 12S rRNA using our

421 preferred set of primers [43]. While we did achieve some results for specimens without

422 observable blood in the digestive tract, we had a much higher success rate for those with

423 observable blood and time and energy could be saved by not extracting DNA from the former

424 group of specimens. We hope that the application of this approach in combination with extensive

425 sampling of additional Triatominae, especially in sylvatic environments, can offer critical and

426 robust data on potential vectors and help to impede the spread of Chagas disease.

Acknowledgements

We thank Jason Cryan, Andrew Ernst, Dimitri Forero, Sarah Frankenberg, Jeremy Huff,

430 Warren Macdonald, Michael E. Irwin, J.J. Ramirez, Gavin Svenson, Julie Urban, and Michael

431 Whiting for donations of specimens; and two reviewers for valuable suggestions that greatly

432 improved this manuscript.

433

1. Otálora-Luna F, Pérez-Sánchez AJ, Sandoval C, Aldana E. Evolution of hematophagous habit in

435 Triatominae (Heteroptera: Reduviidae). Rev Chil Hist Nat. 2015;88: 4. doi:10.1186/s40693-014-

$436 \quad 0032-0$

437 2. Justi SA, Russo CAM, Mallet JR dos S, Obara MT, Galvão C. Molecular phylogeny of Triatomini

438 (Hemiptera: Reduviidae: Triatominae). Parasit Vectors. 2014;7: 149. doi:10.1186/1756-3305-7-149

439 3. Pereira PCM, Navarro EC. Challenges and perspectives of Chagas disease: a review. J Venom Anim 
Toxins Incl Trop Dis. 2013;19: 34. doi:10.1186/1678-9199-19-34

441 4. Bonney KM. Chagas disease in the 21 st century: a public health success or an emerging threat?

$442 \quad$ Parasite. 2014;21: 11. doi:10.1051/parasite/2014012

443 5. Viotti R, Alarcón de Noya B, Araujo-Jorge T, Grijalva MJ, Guhl F, López MC, Ramsey JM, Ribeiro

444 I, Schijman AG, Sosa-Estani S, Torrico F, Gascon J. Towards a paradigm shift in the treatment of

445 chronic Chagas disease. Antimicrob Agents Chemother. 2014;58: 635-639. doi:10.1128/AAC.01662-

$446 \quad 13$

447 6. Lent H, Wygodzinsky P. Revision of the Triatominae (Hemiptera, Reduviidae), and their significance $448 \quad$ as vectors of Chagas’ disease. Bull Am Mus Nat Hist. 1979;163: 123-520.

449 7. Galvão C, Justi SA. An overview on the ecology of Triatominae (Hemiptera:Reduviidae). Acta Trop. $450 \quad$ 2015;151: 116-125. doi:10.1016/j.actatropica.2015.06.006

451 8. Deane LM. Animal reservoirs of Trypanosoma cruzi in Brazil. Rev Bras Malariol Doencas Trop. $452 \quad 1964 ; 16: 27-48$.

453 9. Pizarro JC, Stevens L. A new method for forensic DNA analysis of the blood meal in Chagas disease 454 vectors demonstrated using Triatoma infestans from Chuquisaca, Bolivia. PLoS One.

$455 \quad$ journals.plos.org; 2008;3: e3585. doi:10.1371/journal.pone.0003585

456 10. Feliciangeli MD, Dujardin J-P, Bastrenta B, Mazzarri M, Villegas J, Flores M, Muñoz M. Is

457 Rhodnius robustus (Hemiptera: Reduviidae) responsible for Chagas disease transmission in Western 458 Venezuela? Trop Med Int Health. 2002;7: 280-287.

459 11. Guhl F, Pinto N, Aguilera G. Sylvatic triatominae: a new challenge in vector control transmission.

460 Mem Inst Oswaldo Cruz. 2009;104 Suppl 1: 71-75.

461 12. Usinger RL. The Triatominae of North and Central America and the West Indies and their public 462 health significance. Public Health Bulletin 288, Washington: US Public Health Service; 1944.

463 13. Oliveira MA, Ferreira RL, Carneiro MA, Diotaiuti L. Ecology of Cavernicola pilosa Barber, 1937

464 (Hemiptera: Reduviidae: Triatominae) in the Boa Esperança Cave, Tocantins, Brazil. Ecotropica. $465 \quad 2008 ; 14: 63-68$. 
466 14. Salvatella AR, Basmadjian Y, Rosa R, Puime A. Triatoma delpontei Romana \& Abalos, 1947

467 (Hemiptera, Tratominae) in the Brazilian State of Rio Grande do Sul. Rev Inst Med Trop Sao Paulo. $468 \quad$ 1992;35: 73-76.

469 15. Garrouste R. La première observation in natura de l'entomophagie de Panstrongylus geniculatus 470 (Latreille 1811) hématophage vecteur de la maladie de Chagas (Hemiptera: Reduviidae). Ann Soc 471 Entomol Fr. 2009;45: 302-304. doi:10.1080/00379271.2009.10697614

472 16. Sandoval CM, Ortiz N, Jaimes D, Lorosa E, Galvão C, Rodriguez O, Scorza JV, Gutiérrez R. Feeding 473 behaviour of Belminus ferroae (Hemiptera: Reduviidae), a predaceous Triatominae colonizing rural 474 houses in Norte de Santander, Colombia. Med Vet Entomol. 2010;24: 124-131. doi:10.1111/j.1365$475 \quad 2915.2010 .00868 . x$

476 17. Kjos SA, Marcet PL, Yabsley MJ, Kitron U, Snowden KF, Logan KS, Barnes JC, Dotson EM. 477 Identification of bloodmeal sources and Trypanosoma cruzi infection in triatomine bugs (Hemiptera: 478 Reduviidae) from residential settings in Texas, the United States. J Med Entomol. 2013;50: 1126479 1139. doi:10.1603/ME12242

18. Sandoval CM, Duarte R, Gutíerrez R, Rocha D da S, Angulo VM, Esteban L, Reyes M, Jurberg J, Galvão C. Feeding sources and natural infection of Belminus herreri (Hemiptera, Reduviidae, Triatominae) from dwellings in Cesar, Colombia. Mem Inst Oswaldo Cruz. 2004;99: 137-140. doi:10.1590/S0074-02762004000200004

19. Díaz-Albiter HM, Ferreira TN, Costa SG, Rivas GB, Gumiel M, Cavalcante DR, Pavan MG, Gonzalez MS, de Mello CB, Dillon VM, Bruno RV, Garcia E de S, Lima MM, de Castro DP, Dillon RJ, de Azambuja P, Genta FA. Everybody loves sugar: first report of plant feeding in triatomines. Parasit Vectors. 2016;9: 114. doi:10.1186/s13071-016-1401-0

20. Durán P, Siñani E, Depickère S. On triatomines, cockroaches and haemolymphagy under laboratory conditions: new discoveries. Mem Inst Oswaldo Cruz. 2016;111: 605-613. doi:10.1590/007402760160027

21. Carcavallo RU, da Silva Rocha D, Galindez Giron I. Feeding sources and patterns. In: Carcavallo 
492

493

494

495

496

497

498

499

500

501

502

503

504

505

506

507

508

509

510

511

512

513

\section{4}

515

516

517

RU, Galindez Giron I, Jurberg J, editors. Atlas of Chagas' disease vectors in the Americas Vol 2. 1998. pp. 537-560.

22. Packchanian A. Experimental transmission of Trypanosoma cruzi infection in animals by Triatoma sanguisuga ambigua. Public Health Rep. Association of Schools of Public Health; 1940;55: 15261532. doi: $10.2307 / 4583416$

23. Sant'Anna MRV, Diotaiuti L, de Figueiredo Gontijo A, de Figueiredo Gontijo N, Pereira MH. Feeding behaviour of morphologically similar Rhodnius species: influence of mechanical characteristics and salivary function. J Insect Physiol. 2001;47: 1459-1465.

24. Bodin A, Vinauger C, Lazzari CR. Behavioural and physiological state dependency of host seeking in the blood-sucking insect Rhodnius prolixus. J Exp Biol. 2009;212: 2386-2393. doi:10.1242/jeb.030668

25. Martínez-Ibarra JA, Alejandre-Aguilar R, Paredes-González E, Martínez-Silva MA, Solorio-Cibrián M, Nogueda-Torres B, Trujillo-Contreras F, Novelo-López M. Biology of three species of North American Triatominae (Hemiptera: Reduviidae: Triatominae) fed on rabbits. Mem Inst Oswaldo Cruz. 2007;102: 925-930.

26. Gürtler RE, Ceballos LA, Ordóñez-Krasnowski P, Lanati LA, Stariolo R, Kitron U. Strong hostfeeding preferences of the vector Triatoma infestans modified by vector density: implications for the epidemiology of Chagas disease. PLoS Negl Trop Dis. 2009;3: e447. doi:10.1371/journal.pntd.0000447

27. Barretto MP. Estudos sobre reservatorios e vectores silvestres do Trypanosoma cruzi. 17. Contribuiçao para o estudo dos focos naturais da tripanossomose americana, con especial referência a regiao nordeste do Estado de Sao Paulo, Brasil. Rev Soc Bras Med Trop. 1967;1: 23-35.

28. Freitas J, Siqueira AF, Ferreira OA. Investigações epidemiológicas sobre triatomíneos de hábitos domésticos e silvestres com auxílio da reação de precipitina. Rev Inst Med Trop Sao Paulo. 1960;2: 90-99.

29. Pipkin AC. Reduviid bugs from central Panama and incidence of infection with hemoflagellates. J 
Parasitol. 1962;48: 103-111.

519 30. Christensen HA, de Vasquez AM. Host feeding profiles of Rhodnius pallescens (Hemiptera:

520 Reduviidae) in rural villages of Central Panama. Am J Trop Med Hyg. 1981;30: 278-283.

521 31. Villela MM, Rodrigues VLCC, Casanova C, Dias JCP. Analysis on the food source of Panstrongylus

522 megistus (Hemiptera, Reduviidae, Triatominae) and its present importance as a vector for

523 Trypanosoma cruzi, in the State of Minas Gerais. Rev Soc Bras Med Trop. 2010;43: 125-128.

524 32. Lorosa ES, de Andrade RE, Pujol-Luz JR, Jurberg J, Carcavallo RU. Determinação das fontes

525 alimentares e da infecção natural do Triatoma jurbergi (Carcavallo, Galvão \& Lent, 1998) e Triatoma

526 vandae Carcavallo, Jurberg, Rocha, Galvão, Noireau \& Lent, 2001 capturados no estado do Mato

527 Grosso, Brasil. Zoociências. 2003;5: 243-252.

528 33. Baker M. Reproducibility crisis: Blame it on the antibodies. Nature. 2015;521: 274-276.

529 doi:10.1038/521274a

530 34. Mota J, Chacón JC, Gutiérrez-Cabrera AE, Sánchez-Cordero V, Wirtz RA, Ordoñez R, Panzera F,

531 Ramsey JM. Identification of blood meal source and infection with Trypanosoma cruzi of Chagas

532 disease vectors using a multiplex cytochrome b polymerase chain reaction assay. Vector Borne

533 Zoonotic Dis. 2007;7: 617-627. doi:10.1089/vbz.2007.0106

534 35. Dias FBS, Quartier M, Romaña CA, Diotaiuti L, Harry M. Tamandua tetradactyla Linnaeus, 1758

535 (Myrmecophagidae) and Rhodnius robustus Larrousse, 1927 (Triatominae) infection focus by

536 Trypanosoma rangeli Tejera, 1920 (Trypanosomatidae) in Attalea phalerata Mart. ex Spreng

537 (Arecaceae) palm tree in the Brazilian Amazon. Infect Genet Evol. 2010;10: 1278-1281.

538 doi:10.1016/j.meegid.2010.06.020

539 36. Stevens L, Dorn PL, Hobson J, de la Rua NM, Lucero DE, Klotz JH, Schmidt JO, Klotz SA. Vector

$540 \quad$ blood meals and Chagas disease transmission potential, United States. Emerg Infect Dis. 2012;18:

$541 \quad$ 646-649. doi:10.3201/eid1804.111396

542 37. Lucero DE, Ribera W, Pizarro JC, Plaza C, Gordon LW, Peña R Jr, et al. Sources of blood meals of

543 sylvatic Triatoma guasayana near Zurima, Bolivia, assayed with qPCR and 12S cloning. PLoS Neg1 
544

545

546

547

548

549

550

551

552

553

554

555

556

557

558

559

560

561

562

563

564

565

566

567

568

569

Trop Dis. 2014;8: e3365. doi:10.1371/journal.pntd.0003365

38. Moncayo A, Silveira AC. Current epidemiological trends for Chagas disease in Latin America and future challenges in epidemiology, surveillance and health policy. Mem Inst Oswaldo Cruz. 2009;104 Suppl 1: 17-30.

39. Quinde-Calderón L, Rios-Quituizaca P, Solorzano L, Dumonteil E. Ten years (2004-2014) of Chagas disease surveillance and vector control in Ecuador: successes and challenges. Trop Med Int Health. 2016;21: 84-92. doi:10.1111/tmi.12620

40. Cecere MC, Leporace M, Fernández MP, Zárate JE, Moreno C, Gürtler RE, Cardinal MV. Hostfeeding sources and infection with Trypanosoma cruzi of Triatoma infestans and Triatoma eratyrusiformis (Hemiptera: Reduviidae) from the Calchaqui valleys in Northwestern Argentina. $\mathrm{J}$ Med Entomol. 2016; doi:10.1093/jme/tjw002

41. Cantillo-Barraza O, Garcés E, Gómez-Palacio A, Cortés LA, Pereira A, Marcet PL, Jansen AM, Triana-Chávez O. Eco-epidemiological study of an endemic Chagas disease region in northern Colombia reveals the importance of Triatoma maculata (Hemiptera: Reduviidae), dogs and Didelphis marsupialis in Trypanosoma cruzi maintenance. Parasit Vectors. 2015;8: 482. doi:10.1186/s13071$015-1100-2$

42. Rabinovich JE, Kitron UD, Obed Y, Yoshioka M, Gottdenker N, Chaves LF. Ecological patterns of blood-feeding by kissing-bugs (Hemiptera: Reduviidae: Triatominae). Mem Inst Oswaldo Cruz. Fundação Oswaldo Cruz; 2011;106: 479-494. doi:10.1590/S0074-02762011000400016

43. Kitano T, Umetsu K, Tian W, Osawa M. Two universal primer sets for species identification among vertebrates. Int J Legal Med. 2007;121: 423-427. doi:10.1007/s00414-006-0113-y

44. Hwang WS, Zhang G, Maslov D, Weirauch C. Infection rates of Triatoma protracta (Uhler) with Trypanosoma cruzi in Southern California and molecular identification of trypanosomes. Am J Trop Med Hyg. 2010;83: 1020-1022. doi:10.4269/ajtmh.2010.10-0167

45. Alcaide M, Rico C, Ruiz S, Soriguer R, Muñoz J, Figuerola J. Disentangling vector-borne transmission networks: a universal DNA barcoding method to identify vertebrate hosts from 
arthropod bloodmeals. PLoS One. 2009;4: e7092. doi:10.1371/journal.pone.0007092

571

572

573

574

575

576

577

578

579

580

581

582

583

584

585

586

587

588

589

590

591

592

593

594

595

46. Maslov DA, Lukeš J, Jirku M, Simpson L. Phylogeny of trypanosomes as inferred from the small and large subunit rRNAs: implications for the evolution of parasitism in the trypanosomatid protozoa. Mol Biochem Parasitol. 1996;75: 197-205. doi:10.1016/0166-6851(95)02526-X

47. Melton T, Holland C. Routine forensic use of the mitochondrial 12S ribosomal RNA gene for species identification. J Forensic Sci. 2007;52: 1305-1307. doi:10.1111/j.1556-4029.2007.00553.x

48. Ngo KA, Kramer LD. Identification of mosquito bloodmeals using polymerase chain reaction (PCR) with order-specific primers. J Med Entomol. 2003;40: 215-222.

49. Palumbi SR, Martin A, Romano S, McMillian WO, Stine L, Grabowski G. Simple fool's guide to PCR, Version 2. University of Hawaii, Zoology Department, Honolulu; 1991;

50. Katoh K, Standley DM. MAFFT multiple sequence alignment software version 7: improvements in performance and usability. Mol Biol Evol. 2013;30: 772-780. doi:10.1093/molbev/mst010

51. Sempertegui-Sosa C. Phylogenetic and phylogeographic studies of Panstrongylus sp., vectors of Chagas Disease in Loja and Manabí Provinces, Ecuador. Ohio University. 2012. Available: http://rave.ohiolink.edu/etdc/view?acc_num=ohiou1343799373

52. Gottdenker NL, Chaves LF, Calzada JE, Saldaña A, Carroll CR. Host life history strategy, species diversity, and habitat influence Trypanosoma cruzi vector infection in Changing landscapes. PLoS Neg1 Trop Dis. 2012;6: e1884. doi:10.1371/journal.pntd.0001884

53. Waleckx E, Suarez J, Richards B, Dorn PL. Triatoma sanguisuga blood meals and potential for Chagas disease, Louisiana, USA. Emerging Infectious Diseases. 2014;20: 2141. doi:10.3201/eid2012.131576

54. Ferreira LC, Deane LM. Nôvo depositário silvestre do Schizotrypanum cruzi (Chagas, 1909): a Irára, Tayra barbara. Brasil Med. 1938;52: 1159-1161.

55. Lisboa CV, Monteiro RV, Martins AF, Xavier SC das C, Lima VDS, Jansen AM. Infection with Trypanosoma cruzi TcII and TcI in free-ranging population of lion tamarins (Leontopithecus spp): an 11-year follow-up. Mem Inst Oswaldo Cruz. SciELO Brasil; 2015;110: 394-402. doi:10.1590/0074- 
596

597

598

599

600

601

602

603

604

605

606

607

608

609

610

611

612

613

614

615

616

617

618

619

620

621

02760140400

56. Nyakatura K, Bininda-Emonds ORP. Updating the evolutionary history of Carnivora (Mammalia): a new species-level supertree complete with divergence time estimates. BMC Biol. 2012;10: 12. doi:10.1186/1741-7007-10-12

57. Foley NM, Springer MS, Teeling EC. Mammal madness: is the mammal tree of life not yet resolved? Philos Trans R Soc Lond B Biol Sci. 2016;371. doi:10.1098/rstb.2015.0140

58. Fabre P-H, Hautier L, Dimitrov D, Douzery EJP. A glimpse on the pattern of rodent diversification: a phylogenetic approach. BMC Evol Biol. 2012;12: 88. doi:10.1186/1471-2148-12-88

59. Kierszenbaum F, Gottlieb CA, Budzko DB. Antibody-independent, natural resistance of birds to Trypanosoma cruzi infection. J Parasitol. 1981;67: 656-660. doi:10.2307/3280439

60. Urdaneta-Morales S, McLure I. Experimental infections in Venezuelan lizards by Trypanosoma cruzi. Acta Trop. 1981;38: 99-105.

61. Gorchakov R, Trosclair LP, Wozniak EJ, Feria PT, Garcia MN, Gunter SM, Murray KO. 2016. Trypanosoma cruzi infection prevalence and bloodmeal analysis in triatomine vectors of Chagas disease from rural peridomestic locations in Texas, 2013-2014. J Med Entomol. 2016;53: 911-918. doi:10.1093/jme/tjw040

62. Roque ALR, Xavier SCC, da Rocha MG, Duarte ACM, D’Andrea PS, Jansen AM. Trypanosoma cruzi transmission cycle among wild and domestic mammals in three areas of orally transmitted Chagas disease outbreaks. Am J Trop Med Hyg. 2008;79: 742-749.

63. Hodo CL, Hamer SA. Toward an ecological framework for assessing reservoirs of vector-borne pathogens: Wildlife reservoirs of Trypanosoma cruzi across the southern United States. ILAR J. 2017; 1-14. doi:10.1093/ilar/ilx020

64. Thomas ME, Rasweiler JJ IV, D’Alessandro A. Experimental transmission of the parasitic flagellates Trypanosoma cruzi and Trypanosoma rangeli between triatomine bugs or mice and captive neotropical bats. Mem Inst Oswaldo Cruz. Fundação Oswaldo Cruz; 2007;102: 559-565. doi:10.1590/S0074-02762007005000068 
622 65. Rocha FL, Roque ALR, de Lima JS, Cheida CC, Lemos FG, de Azevedo FC, Arrais RC, Bilac D, 623 Herrera HM, Mourão G, Jansen AM. Trypanosoma cruzi infection in neotropical wild carnivores 624 (Mammalia: Carnivora): at the top of the T. cruzi transmission chain. PLoS One. 2013;8: e67463. 625 doi:10.1371/journal.pone.0067463

626 66. Stella M, Selakovic S, Antonioni A, Andreazzi CS. Community interactions determine role of species 627 in parasite spread amplification: the ecomultiplex network model. arXiv. 2017. Available:

628 http://arxiv.org/abs/1706.05121

629 67. Ibarra-Cerdeña CN, Valiente-Banuet L, Sánchez-Cordero V, Stephens CR, Ramsey JM.

630 Trypanosoma cruzi reservoir-triatomine vector co-occurrence networks reveal meta-community

631 effects by synanthropic mammals on geographic dispersal. PeerJ. 2017;5: e3152.

632 doi:10.7717/peerj.3152

633 68. Rengifo-Correa L, Stephens CR, Morrone JJ, Téllez-Rendón JL, González-Salazar C. Understanding 634 transmissibility patterns of Chagas disease through complex vector-host networks. Parasitology.

$635 \quad 2017 ; 144: 760-772$. doi:10.1017/S0031182016002468

636 69. Browne AJ, Guerra CA, Alves RV, da Costa VM, Wilson AL, Pigott DM, Hay SI, Lindsay SW, 637 Golding N, Moyes CL. The contemporary distribution of Trypanosoma cruzi infection in humans, 638 alternative hosts and vectors. Sci Data. 2017;4: 170050. doi:10.1038/sdata.2017.50

639 70. Barrett TV. Advances in triatomine bug ecology in relation to Chagas' disease. Advances in disease $640 \quad$ vector research. 1991. pp. 143-176.

641

642 Supplemental documents

Fig. S1. RaxML tree of Triatominae species with molecular data available (excluding 18S

644 sequence of Belminus herreri and putatively introgressed mitochondrial CytB sequence from

645 Panstrongylus rufotuberculatus) with bootstrap support values shown. Kissing bug species in red 
646 are those for which gut extracts were assayed with primers for vertebrate host and trypanosome 647 DNA.

648 Table S1. Table of sylvatic host records of all Triatominae species.

649 Article S1. Standard protocol for literature review.

$650 \quad$ Article S2. References for Table S1.

651 Data S1. Phylip file of alignment.

652

Data S2. Partitioning scheme as determined by PartitionFinder.

653 